\title{
The Effect of Nanocellulose Addition to Phenol- formaldehyde Adhesive in Water-resistant Plywood Manufacturing
}

\author{
Jakub Kawalerczyk, ${ }^{\mathrm{a}, *}$ Dorota Dziurka, ${ }^{\mathrm{a}}$ Radosław Mirski, ${ }^{\mathrm{a}}$ Joanna Siuda, ${ }^{\mathrm{a}}$ and \\ Kinga Szentner ${ }^{\mathrm{b}}$
}

\begin{abstract}
This study examined the effect of applying cellulose nanoparticles as a filling material for phenol-formaldehyde (PF) resin in the process of manufacturing water-resistant plywood. Based on investigations that concerned the rheological behavior of resin mixture containing various amounts of nanofiller, the modification of resin resulted in a major increase of viscosity. Although Fourier transform infrared spectroscopy did not fully explain the effect of modification on the chemical structure of the adhesive, there was a noticeable improvement in the morphology of cured nanocellulose-reinforced resin. Based on the bonding quality results, the optimum amount of nanocellulose was 3 PBW (parts by weight) per 100 PBW of resin and it allowed the achievement of a notable increase in shear strength values. Moreover, introduction of cellulosic nanoparticles had a positive effect on mechanical properties such as bending strength and modulus of elasticity. In summary, the research showed that it is possible to apply nanocellulose as a modifier for the adhesives in the process of manufacturing water-resistant plywood.
\end{abstract}

Keywords: Phenol-formaldehyde adhesive; Nanocellulose; NCC; Plywood; Filler; Resin

Contact information: a: Department of Wood-based Materials, Faculty of Wood Technology, Poznan University of Life Sciences, 28 Wojska Polskiego Str., 60-637 Poznań, Poland; b: Department of Chemistry, Faculty of Wood Technology, Poznań University of Life Sciences, 75 Wojska Polskiego Str., 60637 Poznań, Poland; *Corresponding author: jakub.kawalerczyk@up.poznan.pl

\section{INTRODUCTION}

In the last 20 years, global production of wood-based materials has significantly increased due to the growing demand for both finishing and construction materials. This tendency results from the continual growth of other industries such as eco-friendly buildings and furniture (Pawlak and Boruszewski 2018; Kawalerczyk et al. 2019a). The potential application of wood-based materials depends on their properties, and the selection of resin has a major effect on materials performance. Adhesives, depending on the type, have specific properties such as wettability (Stöckel et al. 2010), chemical properties (Dunky and Niemz 2013), distribution (Loxton et al. 2007; Pakdel et al. 2008), and penetration (Liu et al. 2014).

Phenol-formaldehyde (PF) adhesive has been used in the wood-based materials industry for over 100 years. Because of its water, heat, wear resistance, strength, and chemical stability, it is a popular binding agent for gluing wood. Studies have demonstrated that PF resins can infiltrate the cell walls of wood (Liang et al. 2011; Atta-Obeng et al. 2013). The phenolic resins, because of the cell walls and lumens penetration, create the bonds characterized by a great resistant to hydrolysis, mechanical stability, and durability 
(Hunt et al. 2010). Moreover, PF adhesive can improve the hardness of cell walls (Liu et al. 2014). Despite its many undeniable advantages, studies to improve certain properties of $\mathrm{PF}$ are still ongoing. One of the methods of resin modification that leads to improvement of the wood-based materials' properties is modification of their chemistry (Dziurka and Mirski 2010, 2014; Mirski et al. 2011). An alternative way to produce materials with better properties is the introduction of fillers to the adhesives. There are many purposes of the addition of filling substances, such as to adjust the resins viscosity, to improve the bond strength, to reduce the adhesive absorption into a porous veneer surface, to limit the formaldehyde emissions, and to decrease the raw material costs (Sellers et al. 2005; Kawalerczyk et al. 2020b). The filling materials can be added in various forms such as powders (aluminium dioxide, silica), fibers (mica, glass fibers), etc., but they have some properties in common, i.e., fillers are non-volatile, non-gluing, and insoluble in the adhesives (Mahrdt et al. 2016). However, the above-mentioned fillers are characterized by relatively large particle sizes, which makes it difficult to obtain a high level of homogenization of the adhesive mixture. Consequently, it is hard to evenly spread the modified resin on the surface of the veneer or lignocellulosic particles.

The solution may use smaller-sized particles within the dimensional range of nanotechnology (Dukarska and Bartkowiak 2016). Gao and Du (2013) investigated the effect of nano-cupric oxide and surfactants on the curing kinetics of PF resin and properties of plywood. The results showed that the addition of nano-CuO with alkaline surfactant improved the condensation of the PF adhesive. Moreover, the shear strength of plywood manufactured with modified resin has met the requirements of EN 314-2 (1993). Dukarska and Czarnecki (2016) reported an interesting study concerning the introduction of fumed nanosilica as a filler for MUPF resin. Results revealed that the addition of nano-SiO 2 expands the durability and increases reactivity of the resin. The modification also led to a significant decrease of formaldehyde $(\mathrm{HCHO})$ release and allowed the reduction of adhesive consumption in the production process. Furthermore, the introduction of nanosilica to urea-formaldehyde resin made it possible to produce other wood-based materials, such as particleboards and rape straw boards, which were characterized by improved mechanical properties, water resistance, and mycological resistance (Dukarska 2013; Dukarska and Derkowski 2014; Dukarska et al. 2017). In recent studies, Özçifçi et al. (2018) concluded that the bonding strength of wood-based materials manufactured with $\mathrm{TiO}_{2}$ and $\mathrm{SiO}_{2}$-reinforced PF resin was significantly improved. Furthermore, Zhang et al. (2009) revealed that the addition of nano- $\mathrm{BaCO}_{3}$ can effectively delay pyrolysis of $\mathrm{PF}$ resin.

One of the new types of nano-sized fillers is cellulose, a polysaccharide with linear, stereo-regular structure (Hubbe et al. 2008; Ioelovich 2008). The availability of this environmentally friendly polymer is estimated at $1.5 \times 10^{12}$ tons per year (Klemm et al. 2005). Moreover, cellulosic nanoparticles are characterized by the great mechanical properties, such as modulus of elasticity in the range of $138 \mathrm{GPa}$ and strength around 10 GPa (Zimmermann et al. 2004). Both its high energy conversion capacity and chemical compatibility with other substances make it suitable for the use as a modifier of resins (Sokołowska et al. 2008; Abitbol et al. 2016). Using the cellulosic nanoparticles also presents some environmental benefits such as biocompatibility and biodegradability (Lu et al. 2013).

While a considerable amount of research regarding the reinforcement of UF resins with microfibrillated cellulose (MFC) and nanocrystalline cellulose (NCC) can be found, the number of publications on the PF resin modification with natural fibers is scarce 
(Veigel et al. 2011, 2012; Zhang et al. 2011; Ayrilmis et al. 2016b; Mahrdt et al. 2016). Consequently, the aim of this study was to investigate the influence of NCC addition to PF adhesive on the properties of manufactured water-resistant plywood.

\section{EXPERIMENTAL}

The commercially available phenol-formaldehyde (PF) resin was purchased from Silekol Pfleiderer (Kędzierzyn-Koźle, Poland) and it was characterized by the following properties summarized in Table 1.

Table 1. Properties of PF Resin

\begin{tabular}{|c|c|c|}
\hline Properties of Resin & Value & Standard \\
\hline Density $\left(\mathrm{g} / \mathrm{cm}^{3}\right)$ & 1.21 & ISO 8962 (1996) \\
\hline No. 4 Ford Cup viscosity (s) & 153 & EN 12092 (2002) \\
\hline Solid content $(\%)$ & 47 & EN 827 (2005) \\
\hline $\mathrm{pH}$ & 12.52 & EN 1245(2011) \\
\hline Gel time at $130^{\circ} \mathrm{C}(\mathrm{s})$ & 192 & PN-C-89352-3 (1996) \\
\hline
\end{tabular}

The nanocellulose powder (Nanografi Nanotechnology Co., Ltd., Ankara, Turkey) had an average particle sizes declared by the producer to be 10 to $20 \mathrm{~nm}$ wide and 300 to $900 \mathrm{~nm}$ length, and it was used as a modifier for the research purposes. To adjust and regulate the viscosity of the adhesive mixture, the industrially available and common in water-resistant plywood production tannic filler (UT-10) containing mimosa tannins and chalk was added. The reference resin mixture including only mimosa filler was prepared in accordance with technological formulations. Due to the low content of resin dry matter, there was no need to introduce cellulosic nanoparticles in the form of an aqueous suspension. Both fillers in the form of powders were added directly to the adhesive in the amount depending on the variant (Table 2).

Table 2. Compositions of Adhesive Mixtures Depending on the Variant

\begin{tabular}{|c|c|c|}
\hline \multirow{2}{*}{ Variant Label } & \multicolumn{2}{|c|}{ Quantity $\left(\mathrm{g} / 100 \mathrm{~g}\right.$ d.m. ${ }^{1}$ of Resin) } \\
\cline { 2 - 3 } & UT-10 & NCC \\
\hline 0 & 20 & 0 \\
\hline N3 & 15 & 3 \\
\hline N5 & 15 & 5 \\
\hline N7 & 15 & 7 \\
\hline
\end{tabular}

After the addition of the fillers, the mixtures were subjected to a homogenization process with the use of a CAT-500 homogenizer (Ingenieurburo CAT, M. Zipperer GmbH, Ballrechten-Dottingen, Germany) at $1000 \mathrm{rpm}$ for $3 \mathrm{~min}$ to achieve a high level of dispersion of cellulosic nanoparticles. In order to investigate whether there was any major effect of the filler introduction on the chemical structure of cured PF resin, infrared (IR) spectroscopy was performed. Both the control adhesive mixture and experimental mixture labeled as $\mathrm{N} 3$ (which was characterized by the best reinforcement effect in later sections of the study) were condensed at $140{ }^{\circ} \mathrm{C}$, disintegrated in the grinder, and sieved to attain the dimensional fraction retained on the screen with a mesh size of $0.125 \mathrm{~mm}$. The obtained 
powders were mixed with $\mathrm{KBr}$ at a $1 / 200 \mathrm{mg}$ ratio. Spectra were registered using a Nicolet iS5 spectrophotometer (Thermo Fisher Scientific, Waltham, MA, USA) with Fourier transform within a range of 500 to $4000 \mathrm{~cm}^{-1}$ at a resolution of $4 \mathrm{~cm}^{-1}$, registering 16 scans. To assess the rheological behavior of prepared adhesive mixtures, the viscosity test and its changes for $8 \mathrm{~h}$ were characterized using a Brookfield DV-II + Pro viscometer (Middleboro, MA, USA). The morphology of the cured PF resin was evaluated using a scanning electron microscope. The samples were mounted on an aluminum stub with the help of double adhesive carbon tape and coated with a layer of gold (Sputter Coater S150B; Edwards, West Sussex, UK). The structures of cured adhesive mixture (N3) and reference adhesive mixture samples were investigated using a Zeiss Evo 40 analytical scanning electron microscope (Zeiss, White Plains, NY, USA) at an accelerating voltage of $20 \mathrm{kV}$ with the magnification of $500 \times$.

The plywood panels were manufactured in the three-layer system from birch veneers with an average thickness of $1.5 \mathrm{~mm}$ and moisture content of $6 \pm 1 \%$. The adhesives mixtures were spread on the surface of veneer sheets in the amount of $160 \mathrm{~g} / \mathrm{m}^{2}$. The pressing process was conducted at $140{ }^{\circ} \mathrm{C}$ for $4 \mathrm{~min}$, with a unit pressure of $1.4 \mathrm{MPa}$. The average moisture contents of plywood samples were calculated in accordance with EN 322 (1999) and found to be $5 \pm 1 \%$. The manufactured panels were subjected to evaluation of bonding quality according to EN 314-1 (2004) by shear test both after soaking in water at a temperature of $20{ }^{\circ} \mathrm{C}$ for $24 \mathrm{~h}$, and after an aging test. This test involved first boiling the panels in water for $4 \mathrm{~h}$ followed by drying in a laboratory oven at $60{ }^{\circ} \mathrm{C}$ for $18 \mathrm{~h}$, and then boiling them in water for $4 \mathrm{~h}$, and finally cooling them in water at $20{ }^{\circ} \mathrm{C}$ for $1 \mathrm{~h}$. In order to determine the mechanical properties, such as modulus of elasticity (MOE) and bending strength (MOR), tests were conducted in accordance with EN 310 (1993) perpendicular and parallel to the grain of the face veneer layer. The results were subjected to statistical analysis using Tukey test on the significance level of $\alpha=0.05$ with the use of Statistica 13.0 software (StatSoft Inc., Tulsa, OK, USA).

\section{RESULTS AND DISCUSSION}

The viscosity of an adhesive mixture is a key property that determines the suitability of a substance for the use as a filler or modifier in plywood production. As expected, based on previous research, the viscosity of the NCC-modified mixtures increased dramatically compared to the mixtures containing only mimosa filler (Veigel et al. 2012).

The continual increase observed in the viscosity values results with the passage of time most likely resulted from progressive polycondensation reactions of PF resin. Although the particles were not introduced in the form of an aqueous suspension, no dispersion of fillers was observed during the viscosity measurements. For $7 \mathrm{~g}$ of NCC addition to $100 \mathrm{~g} \mathrm{~d}$. $\mathrm{m}$. of solid resin, the viscosity increased $12 \%$ immediately after preparation, and $13 \%$ after $8 \mathrm{~h}$ in comparison to the reference mixtures. The highly hydrophilic cellulosic nanoparticles were absorbing the aqueous medium contained in adhesive mixture. Moreover, the effect may also be explained by a noticeable density of nanocellulose powder and the number of hydroxyl groups located on the surface of the fibrils, which can lead to the formation of temporary bonds between the fibrils (Iotti et al. 2011). This is highly possible, considering the increased chemical activity of nanoparticles in general (Shahbazi et al. 2013). However, the viscosity of the mixtures remained at a proper level that allowed even distribution of the adhesives on the surface and did not cause 
any difficulties during the application on a wavy veneer. Exceedingly low viscosity of the adhesive mixture can lead to difficulties during both the application and pressing processes. It can also result in excessive penetration into the veneer surface and, as a result, the layer remaining on the surface is not able to ensure good properties of the glue joint. The research conducted by Hong and Park (2017) confirms that adjusting the viscosity level can significantly affect the strength properties of the bond.

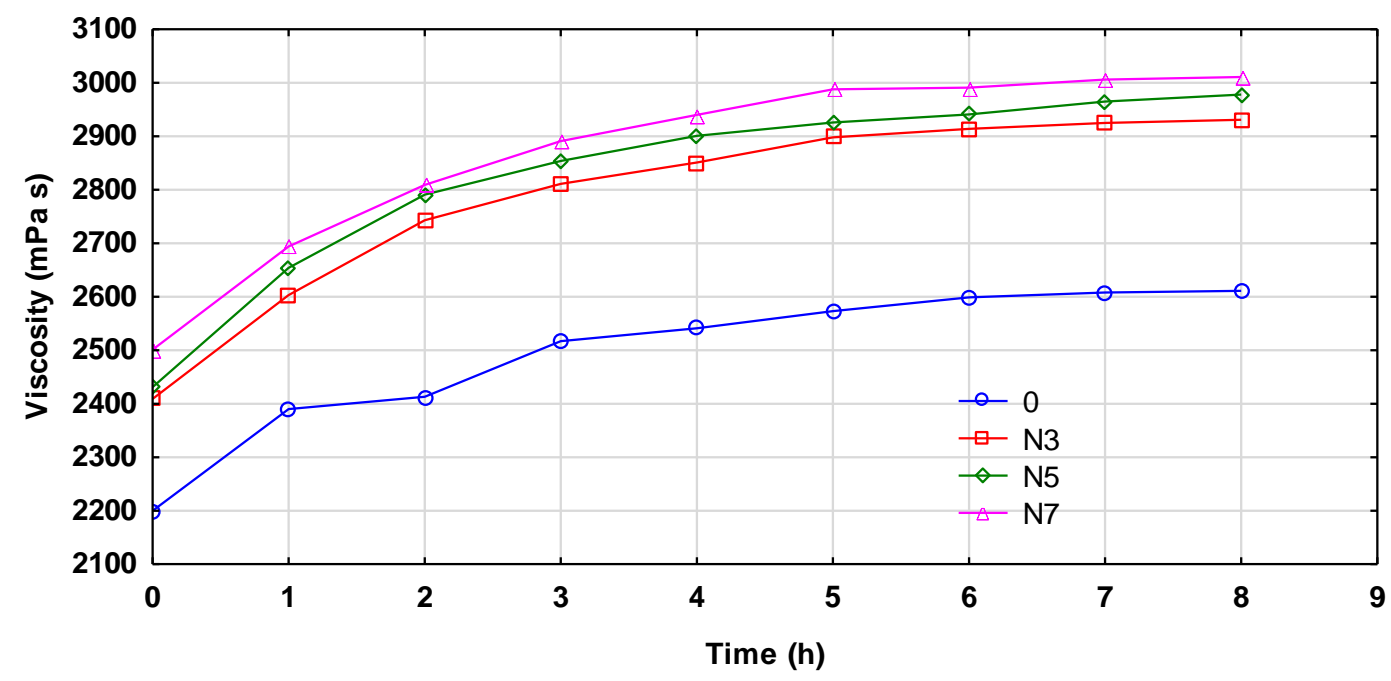

Fig. 1. Viscosity of adhesive mixtures and its changes for $8 \mathrm{~h}$

The surfaces of cellulose nanoparticles are full of hydroxyl groups (Fig. 2). Their location on the equatorial positions of glucopyranose rings makes them highly hydrophilic (Yamane et al. 2006).

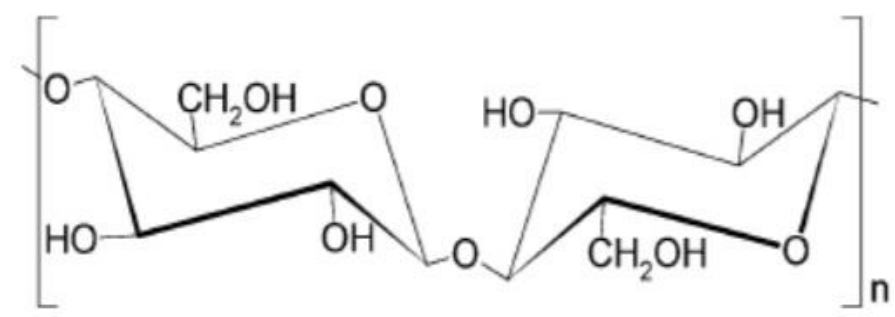

Fig. 2. The chemical structure of cellulose (Atta-Obeng 2011)

According to literature, interfacial bonding of nanocellulose with phenolic resin can be attributed to the reaction between hydroxyl groups of cellulose and the methylol groups of resin (Singha and Thakur 2008). Because the reinforcing effect of NCC is associated with chemical bonding, the Fourier transform infrared was used to investigate the possible interactions between the phenol-formaldehyde adhesive and the cellulosic nanoparticles.

The transmittance spectra of cured, modified, and unmodified PF resins are presented in Fig. 3. Overall, the course of spectra of the conventional and NCC-reinforced adhesives looked similar. Moreover, the spectra of all modified resins were identical, regardless of the variant. Based on a literature review, characteristic peaks were assigned as follows (Holopainen et al. 1998). The broad band at $3400 \mathrm{~cm}^{-1}$ was observed and assigned to the $\mathrm{O}-\mathrm{H}$ stretching of hydroxyl groups in each sample. The $\mathrm{C}-\mathrm{H}$ stretching of 
methylene groups was recorded at $2920 \mathrm{~cm}^{-1}$ (Luo et al. 2015). At a range of 1640 to 1600 $\mathrm{cm}^{-1}$, a clear peak occurred. This peak corresponded to the $\mathrm{C}=\mathrm{C}$ aromatic ring of phenol presented in sample A and B. Moreover, this peak was observed for the nanocellulose sample and was assigned to the $\mathrm{C}=\mathrm{O}$ stretch and overlapped with $\mathrm{OH}$ scissors of water (Poljansek and Krajnc 2005). In the frame of samples A and B, the peaks corresponding to the aromatic ring were presented at $1480 \mathrm{~cm}^{-1}$ and $1430 \mathrm{~cm}^{-1}$. The peak at $1060 \mathrm{~cm}^{-1}$ corresponded to vibration from the pyranose ring (spectra of NCC) (Wulandari et al. 2016). Chen et al. (2016) reported that two peaks at $1115 \mathrm{~cm}^{-1}$ and $915 \mathrm{~cm}^{-1}$ corresponded to the $\mathrm{C}-\mathrm{O}-\mathrm{C}$ pyranose ring skeletal vibration and $\beta$-linkages, respectively.

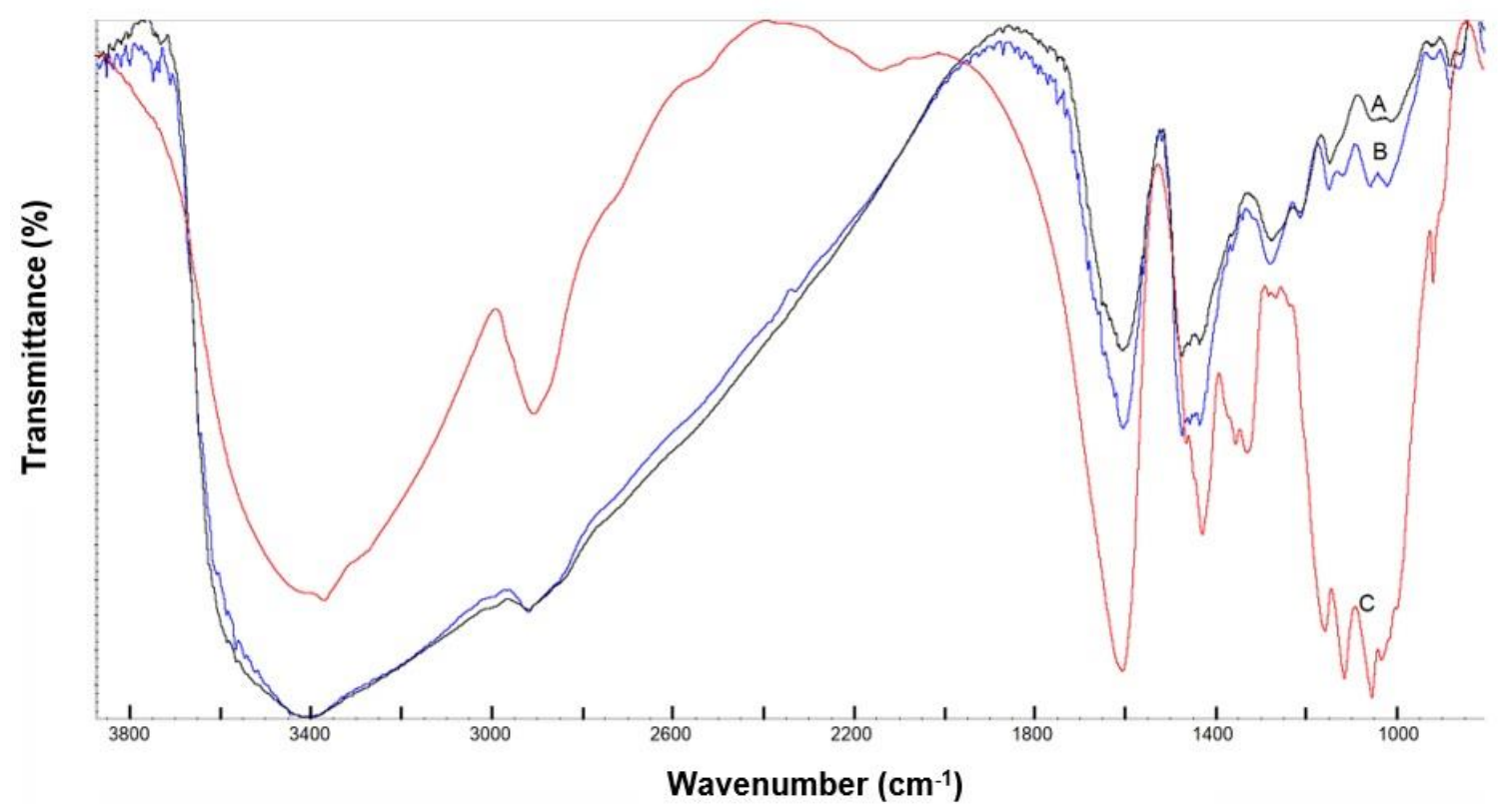

Fig. 3. IR spectra of: (A) - unmodified PF resin; (B) - NCC + PF resin; (C) - NCC

The FTIR spectroscopy did not explain the chemical interaction between the modifier and PF resin and the effect on its chemical structure, like the case of UF resin modification (Kawalerczyk et al. 2020a). Future studies could investigate that using other spectroscopic methods.

The shear strength test is a commonly used indicator of adhesive behavior in plywood (Bekhta et al. 2016; Mirski et al. 2020). Figure 4 presents the results of shear strength investigations conducted both after soaking in water for $24 \mathrm{~h}$ and after the previously described aging test.

The analysis of the data included in Fig. 4 confirmed that the key for achieving the optimum reinforcement effect is the amount of added filler (Veigel et al. 2012). The best results were obtained for the variant with the addition of $3 \mathrm{~g} \mathrm{NCC} / 100 \mathrm{~g} \mathrm{~d} . \mathrm{m}$. of resin. In this case, the shear strength values increased approximately $19 \%$ and $16 \%$ in comparison with reference samples tested after soaking and after boiling, respectively. The addition of $5 \mathrm{~g} \mathrm{NCC} / 100 \mathrm{~g} \mathrm{d.m}$. of resin also led to slightly higher bonding quality compared to the control plywood. However, further addition of cellulosic particles in amount of $7 \mathrm{~g} / 100 \mathrm{~g}$ d.m. of resin caused a major deterioration of bonding quality. A similar tendency was observed by Zhang et al. (2011) in studies on the UF resin reinforcement. The shear 
strength of all plywood samples regardless of the variant retained values exceeded $1 \mathrm{~N} / \mathrm{mm}^{2}$ and met the requirements of EN 314-2 (1993).

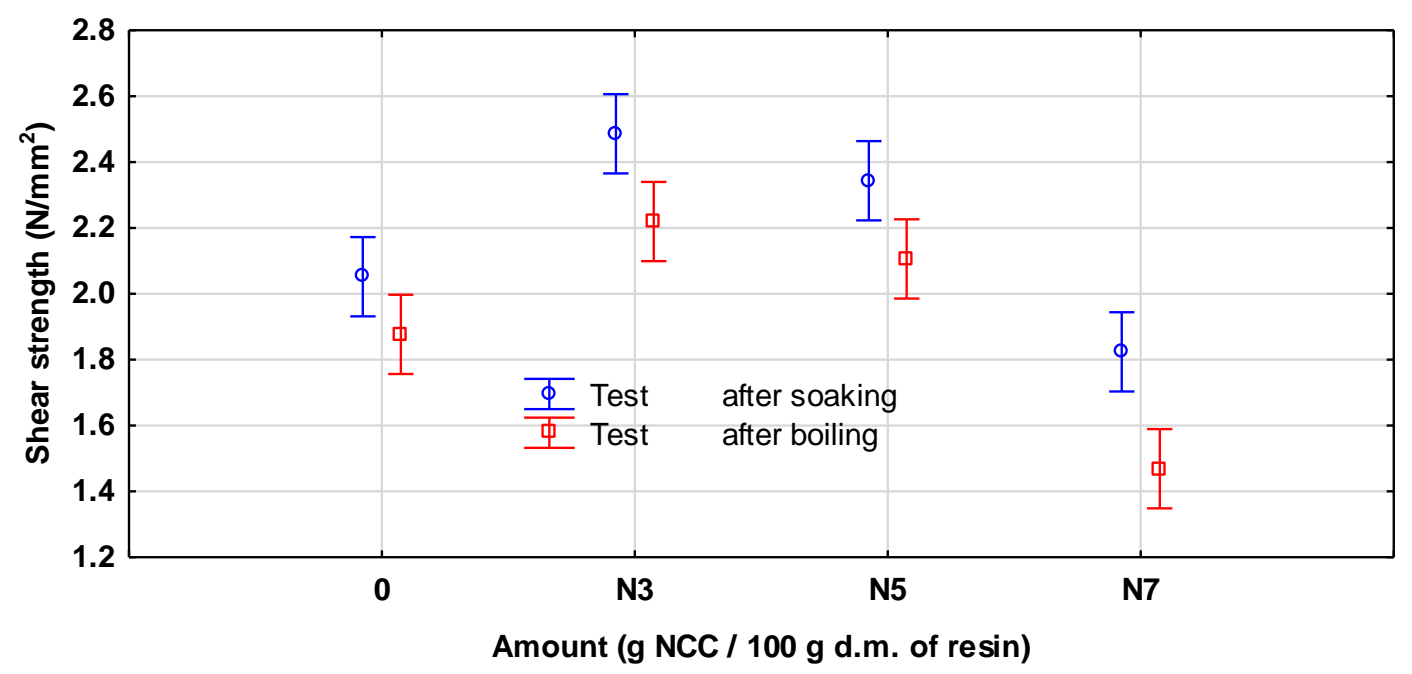

Fig. 4. Shear strength of plywood

The reinforcing effect of nanocellulose addition can be explained by the enhancement in fracture mechanical properties of the glue joint. Studies performed by Vegiel et al. (2011) have shown that the introduction of cellulosic particles can lead to significant improvement in fracture toughness and fracture energy. Moreover, Ayrilmis et al. (2016a) confirmed that the addition of nanocellulose can cause an improvement in plasticity of the wood-adhesive bond. The modification of PF resin with the NCC also caused significant changes in the morphology of cured adhesive cross sections. Based on the SEM images presented in Fig. 5, the nanocellulose-reinforced resin was characterized by a more solid, compact, less porous structure, as noted in the findings of Gao et al. (2012).

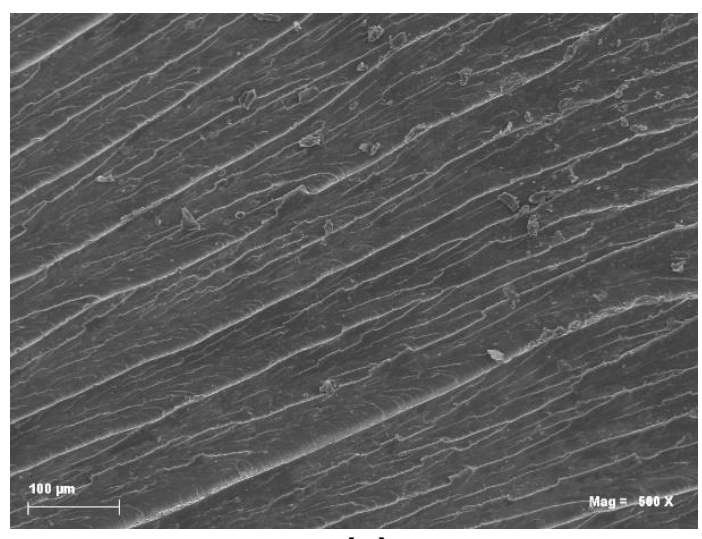

(a)

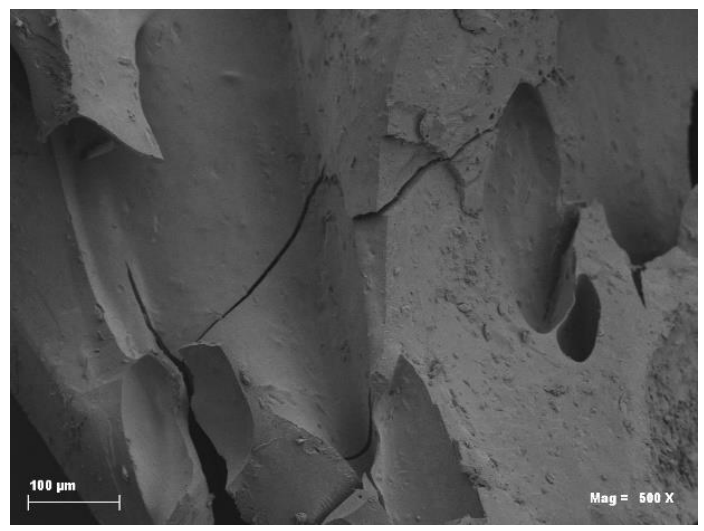

(b)

Fig. 5. SEM images taken with 500x magnification of: (a) NCC-reinforced resin labeled as N3 and $(b)$ reference resin

Limiting the occurrence of microcracks in the bond lines contributes to the improvement in the glue joint strength (Kawalerczyk et al. 2019b). All of the modified variants presented similar differences in adhesive morphology in comparison with 
reference sample. The deterioration observed in the variant containing the highest content of nanoparticles likely resulted from the agglomeration. Nanocellulose act like carriers of load and stress along the polymer matrix. The formation of agglomerates led to the accumulation of stress at a certain point of the bond and consequently decreased its shear strength values (Singha and Thakur 2008).

To fully evaluate the effect of nanocellulose addition to the adhesive mixture on the properties of plywood, the results of bending strength (MOR) and MOE are summarized in Fig. 6.

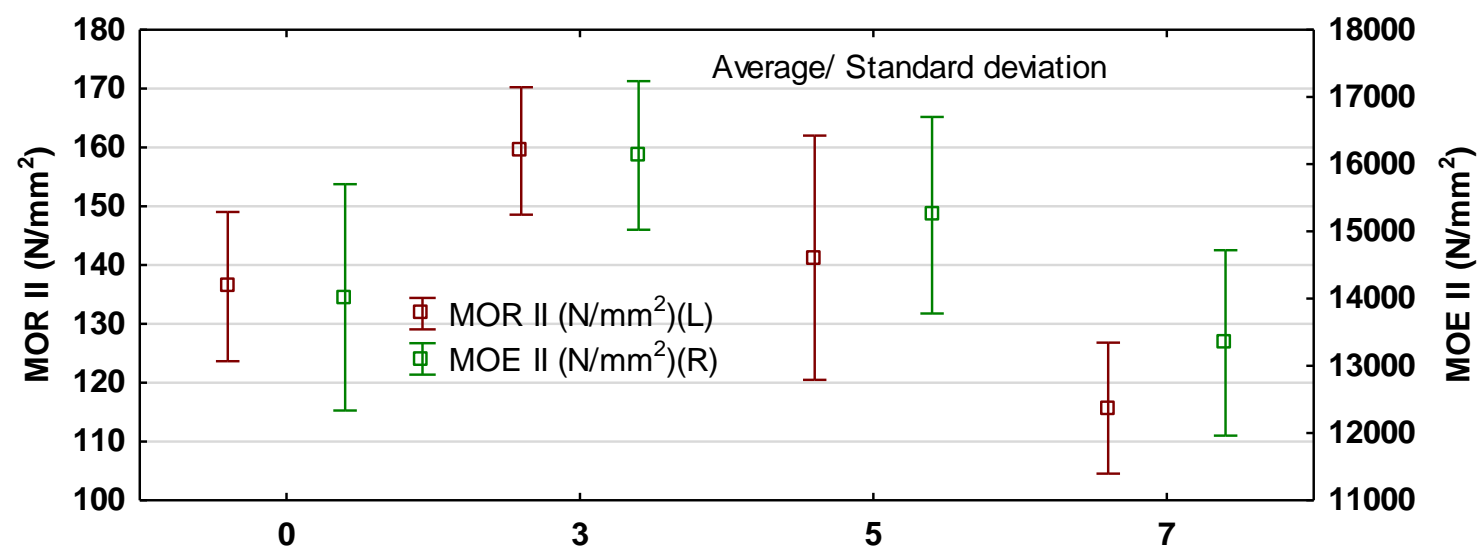

Amount (g NCC / $100 \mathrm{~g}$ d.m. of resin)

(a)

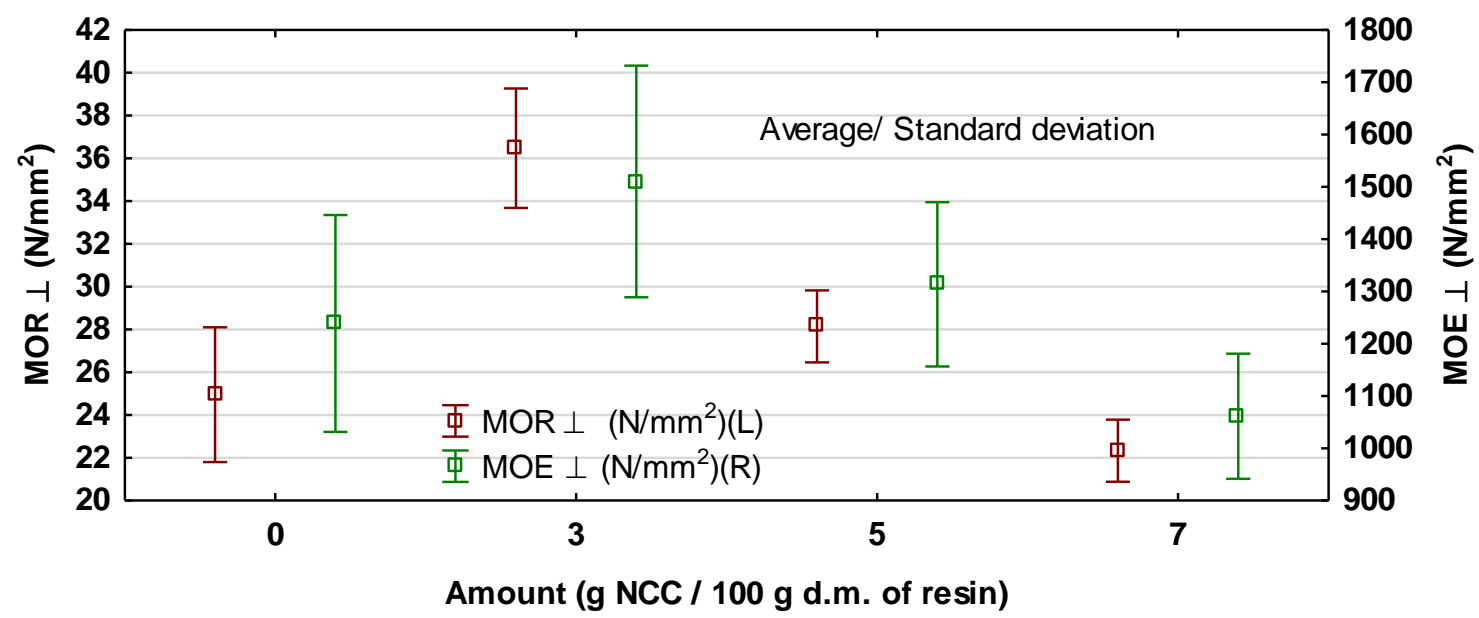

(b)

Fig. 6. Bending strength (MOR) and MOE of plywood tested: (a) parallel and (b) perpendicular to the grains of face veneer layer

The results included in Fig. 5 provide further evidence that adjusting the amount of filler had a dramatic impact on the properties of manufactured plywood. As in the case of the shear strength results, the best values were obtained for the variant assuming the introduction of a small amount, i.e., $3 \mathrm{~g}$ of NCC to $100 \mathrm{~g} \mathrm{d.m}$. of resin. Plywood glued with the adhesive mixture containing $5 \mathrm{~g}$ of NCC achieved slightly better mechanical properties compared to reference panels. Major deterioration of plywood mechanical properties was noted when $7 \mathrm{~g}$ of cellulosic particles were added to PF resin. The results corresponded 
with the shear strength values described earlier. The addition of small amounts of nanocellulose can effectively transfer stress along the bond line (Chirayil et al. 2014). Moreover, during the polycondensation process of wood-adhesive bond, the PF resin penetrated to the surface of the veneer and filled the cell lumens. Liu et al. (2014) reported that the introduction of cellulosic particles can extend the migration of phenolic glue line and consequently leads to significant improvement in the mechanical properties of woodadhesive bonds.

\section{CONCLUSIONS}

1. Based on time-viscosity dependence, introducing nanocellulose into phenolformaldehyde (PF) resin increased its viscosity, which was technologically beneficial.

2. The infrared (IR) spectra of modified and non-modified resin mixtures showed no significant interaction between the cured PF adhesive and the filler.

3. Introduction of cellulosic nanoparticles in the amount of $3 \mathrm{PBW}$ per $100 \mathrm{PBW}$ of the resin guaranteed an optimum reinforcement effect and made it possible to manufacture plywood with a significantly improved bonding quality.

4. Mechanical properties, such as bending strength and modulus of elasticity, of plywood produced with an optimum amount of nanocrystalline cellulose (NCC) was greatly increased in comparison to the control samples.

5. The partial replacement of tannic filler with cellulosic nanoparticles dramatically improved the morphology of the cured adhesive and made the glue joint more durable by eliminating the occurrence of microcracks.

\section{ACKNOWLEDGMENTS}

The paper was partially financed within the framework of Ministry of Science and Higher Education programme 'Regional Initiative of Excellence' in years 2019-2022, Project No. 005/RID/2018/19

\section{REFERENCES CITED}

Abitbol, T., Rivkin, A., Cao, Y., Nevo, Y., Abraham, E., Ben-Shalom, T., Lapidot, S., and Shoseyov, O. (2016). "Nanocellulose, a tiny fiber with huge applications," Current Opinion in Biotechnology 39, 76-88. DOI: 10.1016/j.copbio.2016.01.002

Atta-Obeng, E. (2011). Characterization of Phenol Formaldehyde Adhesive and Adhesive-Wood Particle Composites Reinforced with Microcrystalline Cellulose, Master's Thesis, Auburn University, Auburn, AL, USA.

Atta-Obeng, E., Via, B. K., Fasina, O., Auad, M. L., and Jiang, W. (2013). “Cellulose reinforcement of phenol formaldehyde: Characterization and chemometric elucidation," International Journal of Composite Materials 3(3), 61-68. DOI:

10.5923/j.cmaterials.20130303.04 
Ayrilmis, N., Kwon, J.-H., Lee, S.-H., Han, T.-H., and Park, C.-W. (2016a). "Microfibrillated-cellulose-modified urea-formaldehyde adhesives with different F/U molar ratios for wood-based composites," Journal of Adhesion Science and Technology 30(18), 2032-2043. DOI: 10.1080/01694243.2016.1175246

Ayrilmis, N., Lee, Y.-K., Kwon, J. H., Han, T.-H., and Kim, H.-J. (2016b). "Formaldehyde emission and VOCs from LVLs produced with three grades of ureaformaldehyde resin modified with nanocellulose," Building and Environment 97, 8287. DOI: 10.1016/j.buildenv.2015.12.009

Bekhta, P., Bryn, O., Sedliacik, J., and Novák, I. (2016). "Effect of different fire retardants on birch plywood properties," Acta Facultatis Xylologiae Zvolen 58(1), 5966. DOI: 10.17423/afx.2016.58.1.07

Chen, Y. W., Lee, H. V., and Hamid, S. B. A. (2016). “A response surface methodology study: Effects of trivalent $\mathrm{Cr}^{3+}$ metal ion-catalyzed hydrolysis on nanocellulose crystallinity and yield," BioResources 11(2), 4645-4662. DOI: 10.15376/biores.11.2.4645-4662

Chirayil, C. J., Joy, J., Mathew, L., Koetz, J., and Thomas, S. (2014). "Nanofibril reinforced unsaturated polyester nanocomposites: Morphology, mechanical and barrier properties, viscoelastic behavior and polymer chain confinement," Industrial Crops and Products 56, 246-254. DOI: 10.1016/j.indcrop.2014.03.005

Dukarska, D. (2013). "The effect of an addition of nano- $\mathrm{SiO}_{2}$ to urea resin on the properties of boards manufactured from rape straw," Annals of Warsaw University of Life Sciences-SGGW Forest and Wood Technology 82, 242-245.

Dukarska, D., and Bartkowiak, M. (2016). "The effect of organofunctional nanosilica on the cross-linking process and thermal resistance of UF resin," Journal of Polymer Research 23(8), Article number 166. DOI: 10.1007/s10965-016-1066-6

Dukarska, D., Cofta, G., and Krzykowska, J. (2017). "Resistance of selected wood-based materials glued with nano-SiO2/UF resin to A. niger infestation," Annals of Warsaw University of Life Sciences-SGGW. Forestry and Wood Technology 97, 114-117.

Dukarska, D., and Czarnecki, R. (2016). "Fumed silica as a filler for MUPF resin in the process of manufacturing water-resistant plywood," European Journal of Wood and Wood Products 74(1), 5-14. DOI: 10.1007/s00107-015-0955-4

Dukarska, D., and Derkowski, A. (2014). "Rape straw-wood particleboards resinated with UF resin and supplemented with nano-SiO ${ }_{2}$," Annals of Warsaw University of Life Sciences-SGGW. Forestry and Wood Technology 85, 49-52.

Dunky, M., and Niemz, P. (2013). Holzwerkstoffe und Leime: Technologie und Einflussfaktoren [Wood-Based Materials and Glues: Technology and Influencing Factors], Springer-Verlag, Berlin, Germany.

Dziurka, D., and Mirski, R. (2010). "UF-pMDI hybrid resin for waterproof particleboards manufactured at a shortened pressing time," Drvna Industrija 61(4), 245-249.

Dziurka, D., and Mirski, R. (2014). "Properties of liquid and polycondensed UF resin modified with pMDI," Drvna Industrija 65(2), 115-119. DOI: 10.5552/drind.2014.1321

EN 310 (1993). "Wood-based panels - Determination of modulus of elasticity in bending and of bending strength," European Committee for Standardization, Brussels, Belgium.

EN 314-1 (2004). "Plywood - Bond quality - Test methods," European Committee for Standardization, Brussels, Belgium. 
EN 314-2 (1993). "Plywood - Bond quality - Requirements," European Committee for Standardization, Brussels, Belgium.

EN 322 (1999). "Wood-Based panels - Determination of moisture content," European Committee for Standardization, Brussels, Belgium.

EN 827 (2005). "Adhesives: Determination of conventional solids content and constant mass solids content," European Committee for Standardization, Brussels, Belgium.

EN 1245 (2011). "Adhesives - Determination of pH," European Committee for Standardization, Brussels, Belgium.

EN 12092 (2002). "Adhesives - Determination of viscosity," European Committee for Standardization, Brussels, Belgium.

Gao, Q., Li, J., Shi, S. Q., Liang, K., and Zhang, X. (2012). "Soybean meal-based adhesive reinforced with cellulose nano-whiskers," BioResources 7(4), 5622-5633. DOI: $10.15376 /$ biores.7.4.5622-5633

Gao, W., and Du, G. (2013). "Curing kinetics of nano cupric oxide (CuO)-modified PF resin as wood adhesive: Effect of surfactant," Journal of Adhesion Science and Technology 27(22), 2421-2432. DOI: 10.1080/01694243.2013.780137

Holopainen, T., Alvila, L., Rainio, J., and Pakkanen, T. T. (1998). "IR spectroscopy as a quantitative and predictive analysis method of phenol-formaldehyde resol resins," Journal of Applied Polymer Science 69(11), 2175-2185. DOI: 10.1002/(SICI)10974628(19980912)69:11<2175::AID-APP9>3.0.CO;2-D

Hong, M.-K., and Park, B.-D. (2017). "Effect of urea-formaldehyde resin adhesive viscosity on plywood adhesion," Journal of the Korean Wood Science Technology 45(2), 223-231. DOI: 10.5658/WOOD.2017.45.2.223

Hubbe, M. A., Rojas, O. J., Lucia, L. A., and Sain, M. (2008). "Cellulosic nanocomposites: A review," BioResources 3(3), 929-980. DOI: 10.15376/biores.3.3.929-980

Hunt, C. G., Jakes, J. E., and Grigsby, W. (2010). "Evaluation of adhesive penetration of wood fibre by nanoindentation and microscopy," in: BIOCOMP 2010: 10th Pacific Rim Bio-Based Composites Symposium, Alberta, Canada, pp. 216-226.

Ioelovich, M. (2008). "Cellulose as a nanostructured polymer: A short review," BioResources 3(4), 1403-1418. DOI: 10.15376/biores.3.4.1403-1418

Iotti, M., Gregersen, Ø. W., Moe, S., and Lenes, M. (2011). "Rheological studies of microfibrillar cellulose water dispersions," Journal of Polymers and the Environment 19(1), 137-145. DOI: 10.1007/s10924-010-0248-2

ISO 8962 (1996) - "Plastics - Polymer dispersions - Determination of density," International Organization for Standardization, Geneva, Switzerland.

Kawalerczyk, J., Dziurka, D., Mirski, R., and Grześkowiak, W. (2019a). "The effect of veneer impregnation with a mixture of potassium carbonate and urea on the properties of manufactured plywood," Drewno 62(203), 107-116. DOI: 10.12841/wood.16443985.281.12

Kawalerczyk, J., Dziurka, D., Mirski, R., and Trociński, A. (2019b). "Flour fillers with urea-formaldehyde resin in plywood," BioResources 14(3), 6727-6735. DOI: 10.15376/biores.14.3.6727-6735

Kawalerczyk, J., Dziurka, D., Mirski, R., and Szentner, K. (2020a). "Properties of plywood produced with urea-formaldehyde adhesive modified with nanocellulose and microcellulose,” Drvna Industrija 71(1), 61-67. DOI: 10.5552/drvind.2020.1919 
Kawalerczyk, J., Siuda, J., Mirski, R., and Dziurka, D. (2020b). "Hemp flour as a formaldehyde scavenger for melamine-urea-formaldehyde adhesive in plywood production," BioResources 15(2), 4052-4064. DOI: 10.15376/biores.15.2.4052-4064

Klemm, D., Heublein, B., Fink, H.-P., and Bohn, A. (2005). "Cellulose: Fascinating biopolymer and sustainable raw material," Angewandte Chemie International Edition 44(22), 3358-3393. DOI: 10.1002/chin.200536238

Liang, K., Du, G. B., Hosseinaei, O., Wang, S. Q., and Wang, H. (2011). "Mechanical properties of secondary wall and compound corner middle lamella near the phenolformaldehyde (PF) adhesive bond line measured by nanoindentation," Advanced Materials Research (236-238), 1746-1751. DOI:

10.4028/www.scientific.net/AMR.236-238.1746

Liu, C., Zhang, Y., Wang, S., Meng, Y., and Hosseinaei, O. (2014). "Micromechanical properties of the interphase in cellulose nanofiber-reinforced phenol formaldehyde bondlines," BioResources 9(3), 5529-5541. DOI: 10.15376/biores.9.3.5529-5541

Loxton, C., Thumm, A., Grigsby, W. J., Adams, T. A., and Ede, R. M. (2007). "Resin distribution in medium density fiberboard. Quantification of UF resin distribution on blowline-and dry-blended MDF fiber and panels," Wood and Fiber Science 35(3), 370-380.

Lu, Z., Fan, L., Zheng, H., Lu, Q., Liao, Y., Huang B. (2013). “Preparation, characterization and optimization of nanocellulose whiskers by simultaneously ultrasonic wave and microwave assisted," Bioresource Technology 146, 82-88. DOI: 10.1016/j.biortech.2013.07.047

Luo, J., Zhang, J., Luo, J., Li, J., and Gao, Q. (2015). “Effect of melamine allocation proportion on chemical structures and properties of melamine-urea-formaldehyde resins," BioResources 10(2), 3265-3276. DOI: 10.15376/biores.10.2.3265-3276

Mahrdt, E., Pinkl, S., Schmidberger, C., Van Herwijnen, H. W., Veigel, S., and GindlAltmutter, W. (2016). "Effect of addition of microfibrillated cellulose to ureaformaldehyde on selected adhesive characteristics and distribution in particle board," Cellulose 23(1), 571-580. DOI: 10.1007/s10570-016-0818-5

Mirski, R., Dziurka, D., and Łęcka, J. (2011). "Potential of shortening pressing time or reducing pressing temperature for plywood resinated with PF resin modified using alcohols and esters," European Journal of Wood and Wood Products 69(2), 317-323. DOI: $10.1007 / \mathrm{s} 00107-010-0436-8$

Mirski, R., Kawalerczyk, J., Dziurka, D., Wieruszewski, M., and Trociński, A. (2020). "Effects of using bark particles with various dimensions as a filler for ureaformaldehyde resin in plywood," BioResources 15(1), 1692-1701. DOI: 10.15376/biores.15.1.1692-1701

Özçifçi, A., Kara, M. E., and Kaymakçı, A. (2018). "Impact of PF and MUF adhesives modified with $\mathrm{TiO}_{2}$ and $\mathrm{SiO}_{2}$ on the adhesion strength," Wood Research 63(1), 75-84.

Pakdel, H., Cyr, P.-L., Riedl, B., and Deng, J. (2008). "Quantification of urea formaldehyde resin in wood fibers using X-ray photoelectron spectroscopy and confocal laser scanning microscopy," Wood Science and Technology 42(2), 133-148. DOI: $10.1007 / \mathrm{s} 00226-007-0155-4$

Pawlak, D., and Boruszewski, P. (2018). "Influence of addition of microfibrillated cellulose (MFC) on selected properties of low-density particleboard," Annals of Warsaw University of Life Sciences-SGGW Forestry and Wood Technology 102, 139148. 
PN-C-89352-3 (1996). "Kleje -- Kleje do drewna -- Metody badań -- Oznaczanie czasu żelowania [Wood adhesives test methods - Determination of gelation time]," Polish Committee for Standardization, Warsaw, Poland

Poljansek, I., and Krajnc, M. (2005). "Characterization of phenol-formaldehyde prepolymer resins by in line FT-IR spectroscopy," Acta Chimica Slovenica 52(3), 238-244.

Sellers, T., Miller, G. D., and Smith, W. (2005). "Tool wear properties of five extender/fillers in adhesive mixes for plywood," Forest Products Journal 55(3), 27 31.

Shahbazi, M.-A., Hamidi, M., Mäkilä, E. M., Zhang, H., Almeida, P. V., Kaasalainen, M., Salonen, J. J., Hirvonen, J. T., and Santos, H. A. (2013). "The mechanisms of surface chemistry effects of mesoporous silicon nanoparticles on immunotoxicity and biocompatibility," Biomaterials 34(31), 7776-7789. DOI: 10.1016/j.biomaterials.2013.06.052

Singha, A. S., and Thakur, V. K. (2008). "Fabrication and study of lignocellulosic Hibiscus sabdariffa fiber reinforced polymer composites," BioResources 3(4), 1173 1186. DOI: 10.15376/biores.3.4.1173-1186

Sokołowska, A., Olszyna, A., and Frąckowiak, I. (2008). "Nanotechnologia w inżynierii materiałów drzewnych [Nanotechnology for wood materials engineering]," Inżynieria Materiatowa 29(5), 469-472.

Stöckel, F., Konnerth, J., Kantner, W., Moser, J., and Gindl, W. (2010). "Mechanical characterisation of adhesives in particle boards by means of nanoindentation," European Journal of Wood and Wood Products 68(4) 421-426. DOI: 10.1007/s00107-009-0380-7

Veigel, S., Müller, U., Keckes, J., Obersriebnig, M., and Gindl-Altmutter, W. (2011). "Cellulose nanofibrils as filler for adhesives: Effect on specific fracture energy of solid wood-adhesive bonds," Cellulose 18(5), 1227-1237. DOI: 10.1007/s10570-0119576-1

Veigel, S., Rathke, J., Weigl, M., and Gindl-Altmutter, W. (2012). "Particle board and oriented strand board prepared with nanocellulose-reinforced adhesive," Journal of Nanomaterials 2012(158503), 1-8. DOI: 10.1155/2012/158403

Wulandari, W. T., Rochliadi, A., and Arcana, I. M. (2016). "Nanocellulose prepared by acid hydrolysis of isolated cellulose from sugarcane bagasse," in: IOP Conference Series: Materials Science and Engineering Volume $10710^{\text {th }}$ Joint Conference on Chemistry, Solo, Indonesia, pp. 1-7.

Yamane, C., Aoyagi, T., Ago, M., Sato, K., Okajima, K., and Takahashi, T. (2006). "Two different surface properties of regenerated cellulose due to structural anisotropy," Polymer Journal 38(8), 819-826. DOI: 10.1295/polymj.PJ2005187

Zhang, H., Zhang, J., Song, S., Wu, G., and Pu, J. (2011). "Modified nanocrystalline cellulose from two kinds of modifiers used for improving formaldehyde emission and bonding strength of urea-formaldehyde resin adhesive," BioResources 6(4) 44304438. DOI: 10.15376/biores.6.4.4430-4438

Zhang, X., Ma, Q., Zhang, Z., Peng, W., and Zhang, M. (2009). "Effect of nano $\mathrm{BaCO}_{3}$ on pyrolytic reaction of phenol-formaldehyde resin," in: Second International Conference on Smart Materials and Nanotechnology in Engineering, Weihai, China, pp. 7493. 
Zimmermann, T., Pöhler, E., and Geiger, T. (2004). "Cellulose fibrils for polymer reinforcement," Advanced Engineering Materials 6(9), 754-761. DOI: 10.1002/adem.200400097

Article submitted: March 23, 2020; Peer review completed: May 16, 2020; Revised version received and accepted: May 20, 2020; Published: May 22, 2020.

DOI: $10.15376 /$ biores. 15.3.5388-5401 